\title{
BUDAYA MASYARAKAT DAN IMPLIKASINYA TERHADAP KETERLIBATAN SUAMI DALAM KEGIATAN RUMAH TANGGA
}

\author{
Andi Tenri Ampa \\ BPKB Sulawesi Tenggara \\ Jl. Kijang no. 21 Kendari Sulawesi Tenggara \\ Email :kulau_tenri@yahoo.com
}

\begin{abstract}
Husband's involvement in doing chores is influenced by normative and cultural perception in society based on sex role. In its development, husband and wife division labor changes from traditional perception that posits men as the main leader having special right and big authority in family directing towards androgyny stereotype of which spouse has flexible perception in work division labor.

Keterlibatan suami dalam kegiatan rumah tangga dipengaruhi oleh pandangan normatif dan budaya yang berlaku dalam masyarakat, sesuai dengan peran jenisnya. Dalam perkembangannya, secara budaya pembagian peran suami istri dalam keluarga mengalami pergeseran dari sudut pandang tradisional dimana laki-laki adalah sebagai penguasa utama rumah tangga yang memiliki hak-hak istimewa dan otoritas terbesar dalam keluarga ke arah stereotip androgin dimana suami istri mempunyai pandangan yang fleksibel dalam pembagian peran dalam rumah tangga.
\end{abstract}

Keywords : normatif, budaya, tradisional, androgin dan rumah tangga

\section{Pendahuluan}

Dalam budaya masyarakat tradisional, peran utama laki-laki adalah penguasa utama rumah tangga yang memiliki hak-hak istimewa dan otoritas terbesar dalam keluarga. Sehingga anggota keluarga lain termasuk istri harus tunduk kepada penguasa utama tersebut. Laki-laki 
dalam posisinya sebagai suami dan ayah merupakan figur sentral dalam keluarga. Kewibawaan, harga diri, dan status ayah atau suami harus dijaga oleh anggota keluarga karena atribut-atribut tersebut sangat menentukan status dan kedudukan keluarga dalam masyarakat (Abdullah, 1997).

Pandangan budaya masyarakat tradisional di atas mendapat tantangan dari Berk dan Laura (1989) yang menyimpulkan bahwa mungkin saja ada beberapa orang yang berpendapat dirinya memiliki ciriciri maskulin maupun ciri-ciri feminin. Individu seperti ini akan menyukai pekerjaan perkayuan maupun masak-memasak, dapat sangat tegas dalam pekerjaan yang menunjukkan sifat maskulin dan sangat lemah lembut bila berada di rumah yang menunjukkan sifat feminin. Individu yang seperti ini oleh Bem disebut androginus psikologis, yang diambil dari istilah Yunani yaitu laki-laki (andro) dan perempuan (gyne). Jadi disini ada pengkombinasian antara ciri-ciri maskulin dan feminin yang kuat.

Individu androgin dapat melebihi individu yang termasuk dalam penggolongan jenis kelamin tradisional karena memiliki perilaku yang lebih luwes, penuh perhatian dan berkompeten serta tidak mengalami kesulitan dalam melakukan kegiatan rumah tangga, termasuk pengasuhan anak. Pendapat ini didukung oleh Atkinson, dan Hilgard (1994) yang menyatakan bahwa individu yang androgin adalah individu yang fleksibel dan dapat berfungsi secara optimal. Individu tersebut bersifat mandiri dan mempunyai pendapat, juga dapat diajak bermain dan mengasuh anak. Individu yang androgin kemungkinan memiliki pandangan yang lebih egaliter sehingga lebih mengarah kepada pandangan yang lebih modern. Dalam keluarga yang mempunyai pandangan modern terdapat struktur pembagian kekuasaan yang fleksibel karena memandang bahwa laki-laki dan perempuan mempunyai kedudukan yang setara, sehingga laki-laki juga diharapkan ikut terlibat dalam kegiatan rumah tangga.

Kedua pandangan tersebut menimbulkan pembagian kerja yang didasarkan pada perbedaan jenis kelamin yang seolah-olah diatur oleh alam dan merupakan kodrat atau sesuatu yang alamiah sifatnya. Hal ini akibat dari keadaan fisik perempuan, alam memberikan tugas kepada perempuan untuk melahirkan dan membesarkan anak-anak. Demikian juga karena keadaan fisik laki-laki, alam memberikan tugas kepadanya menjaga dan menghidupi keluarganya. Lebih lanjut diungkapkan oleh Budiman (1981), 
banyak orang percaya bahwa perempuan sudah sewajarnya hidup di lingkungan rumah tangga, melahirkan dan membesarkan anak, memasak dan memberi perhatian kepada suaminya supaya rumah tangga yang tenteram dan sejahtera dapat diciptakan. Laki-laki mempunyai tugas lain, yaitu pergi ke luar rumah untuk mencari makan bagi keluarganya, baik dengan berburu (pada zaman dahulu) maupun bekerja untuk mendapatkan upah (pada zaman sekarang).

Dalam konsep relasi gender, pembagian kerja yang semula sangat sexist mulai kabur. Jenis pekerjaan tidak selalu dikaitkan dengan jenis kelamin. Pekerjaan suami mulai terlibat pada sektor domestik, sementara istri mulai terbuka pada sektor publik karena suami mulai permisif pada nilai-nilai pemingitan. Suami sebagai pencari nafkah utama mulai melibatkan pihak istri, sementara istri yang mengurus anak dan rumah tangga mulai dibantu suami sehingga pengasuhan anak menjadi tanggung jawab bersama. Dalam hal ini pihak istri mulai independent dalam membuat keputusan sehingga posisinya sebagai sub ordinat makin kabur dan mengarah pada posisi istri sebagai mitra.

Dalam tulisan ini akan dijelaskan pandangan peran gender dalam keluarga yang dimulai dari pandangan masyarakat tradisional sampai dengan pandangan modern yang menolak norma-norma yang berlaku secara tradisional dan menerima prinsip-prinsip egalitarian atau kesetaraan.

\section{Budaya Masyarakat dan Pembagian Peran Gender dalam Keluarga}

Dalam budaya masyarakat tradisional, peran utama laki-laki adalah sebagai penguasa utama rumah tangga yang memiliki hak-hak istimewa dan otoritas terbesar dalam keluarga. Laki-laki dalam posisinya sebagai suami dan ayah merupakan figur sentral dalam keluarga. Kewibawaan, harga diri, dan status ayah atau suami harus dijaga oleh anggota keluarganya karena atribut-atribut tersebut sangat menentukan status dan kedudukan keluarga dalam masyarakat (Abdullah, 1997).

Pengaruh akar sosial budaya tradisional dalam mengasosiasikan perempuan sebagai kelompok orang yang memiliki ciri tertentu telah memberikan warna dalam keterlibatan perempuan dalam kegiatan ekonomi. Pemaknaan keterlibatan perempuan dalam kegiatan ekonomi ini ditentukan oleh sistem nilai adat istiadat yang memberikan peluang sekaligus pembatasan berupa etika, tentang apa yang boleh dan apa 
yang tidak boleh dilakukan. Proses sosialisasi perempuan mengarahkan kepada terjadinya identifikasi pekerjaan-pekerjaan yang sesuai dengan sifat keperempuanannya. Terlihat bahwa perempuan ternyata banyak dilibatkan di sektor-sektor yang sudah terpola pada pekerjaan yang bersifat “menerima perintah". Kecenderungan tersebut terefleksikan dalam konteks yang lebih luas, dimana pihak yang memerintah adalah laki-laki, dan pihak yang menerima perintah adalah perempuan. Selain itu, perempuan sebagai pihak yang menerima perintah, di dalam struktur kekuasaan berada di posisi yang lemah dan terlihat jelas dengan adanya hubungan-hubungan personal yang mempengaruhi ukuran-ukuran kedudukan dan kesempatan. Konstruksi gender ini menempatkan laki-laki pada ujung yang satu dan perempuan pada ujung yang yang lain di sebuah garis vertikal. Secara langsung konstruksi ini menegaskan posisi sub ordinat perempuan dan superioritas laki-laki.

Penjelasan tersebut menunjukkan betapa hegemoni patriarkhi melingkupi pola relasi gender lokal. Dalam konteks ini pembagian kerja menjadi sexist dan dibedakan dalam suatu dikhotomi dari waktu ke waktu. Relasi gender menjadi perilaku spesifik yang diharapkan dan dijadikan standar yang diterapkan pada laki-laki dan perempuan, dimana penyimpangan subjek dari ketentuan ini akan mendapatkan sanksi sosial (penilaian negatif) masyarakat. Dengan kata lain, pola relasi gender ini merupakan tingkah laku yang cocok untuk tiap-tiap jenis kelamin. Dalam hal ini kelompok laki-laki diharapkan akan menjadi maskulin dan perempuan diharapkan menjadi feminin.

Suami yang dibesarkan untuk menjadi keras, tegar, jantan, maskulin, mandiri, kemungkinan akan mengalami konflik bila memberikan bantuan dalam tugas rumah tangga dan merawat anak, karena dianggap bahwa tugas perempuan. Oleh karena masyarakat dianggap sebagai bentuk makro dari keluarga, maka kedudukan laki-laki dalam keluarga memberikan legitimasi bagi laki-laki untuk mendapatkan prestise dan kekuasaan dalam masyarakat. Suami menginginkan agar istri dan anakanak dapat tunduk kepadanya dan suami sebagai kepala rumah tangga, mempunyai kekuasaan yang lebih tinggi dibanding anggota keluarga yang lain. Akibatnya untuk memberikan bantuan dalam tugas rumah tangga dan merawat anak, kemungkinan mereka akan mengalami konflik internal dan 
secara emosional akan menimbulkan kesulitan karena mereka menganggap bahwa itu adalah tugas perempuan. Rowatt (1990) juga menambahkan bahwa pekerjaan rumah tangga sebagai pekerjaan yang tidak menantang bakat-bakat intelektual serta kreativitas dan tugas tanpa ucapan terima kasih.

Ward (Hurlock,1992) merumuskan peran gender dengan pernyataan bahwa peran jenis kelamin yang ditentukan secara budaya mencerminkan perilaku dan sikap yang umumnya disetujui sebagai maskulin atau feminin dalam suatu budaya tertentu. Menurut Berk (1989), peran gender saling berkaitan dengan stereotip jenis kelamin yang membedakan secara jelas bahwa peran perempuan berlawanan dengan peran laki-laki. Sejalan dengan pendapat di atas, Ruble \& Ruble (dalam Berk, 1989) menjelaskan bahwa peran gender adalah stereotip jenis kelamin yang mengacu kepada kepercayaan yang dianut masyarakat luas tentang karakteristik jenis kelamin laki-laki yang berlawanan dengan karakteristik jenis kelamin perempuan. Dari ketiga pendapat di atas dapat disimpulkan bahwa peran gender adalah sekumpulan pola tingkah laku atau sikap yang dituntut oleh lingkungan dan budaya tempat individu itu berada untuk ditampilkan secara berbeda oleh laki-laki dan perempuan sesuai jenis kelaminnya.

Menurut Sconzoni dan John (1981) secara teori dalam budaya masyarakat pembagian peran dan keterlibatan suami dalam kehidupan rumah tangga dapat dibagi menjadi beberapa struktur, diantaranya adalah :

\section{a. Structural Functionalism Theory}

Teori ini memandang masyarakat sebagai sistem yang terdiri atas bagian yang saling berkaitan. Masing-masing struktur dalam masyarakat seperti agama, pendidikan, struktur politik dan rumah tangga, secara terus menerus mencari keseimbangan (equilibrium) dan harmoni. Adapun interrelasi terjadi karena adanya konsensus. Pola yang nonnormatif dianggap akan melahirkan gejolak. Jika hal itu terjadi maka masing-masing bagian akan cepat menyesuaikan diri untuk mencapai keseimbangan kembali. Jika suami terlibat dalam urusan rumah tangga, akan terjadi pola yang non normatif yaitu suami sesuai dengan sifat instrumental yang mampu bersaing, teguh, yakin pada kemampuan diri dan rasional, lebih mendukung fungsi suami untuk sukses di dunia luar rumah. 


\section{b. Conflict theory}

Dalam keluarga, terjadi konflik antara cinta dan kasih sayang dengan kekuasaan. Hal ini karena individu yang terlibat dalam keluarga adalah individu yang masing-masing memiliki kepribadian, minat dan tujuan yang berbeda. Suami merasa mendapat legitimasi kekuasaan dan istri tergantung secara keuangan kepada suami, sehingga suami mengalami konflik antara melestarikan kekuasaan dan membantu pekerjaan rumah tangga untuk membuktikan rasa cinta terhadap istrinya.

c. Symbolic Interaction Theory.

Suami dapat menyalahartikan gerakan atau ucapan yang diungkapkan oleh istri. Simbol-simbol yang tampak seringkali tidak dimengerti oleh suami, akibat komunikasi yang kurang terbuka antar kedua pasangan tersebut. Dengan adanya berbagai peran yang disandang oleh individu, membutuhkan keterbukaan dan penyesuaian baru yang selaras dengan situasi, harapan dan kebutuhan bersama, sehingga tercipta kerja sama yang baik dalam menyelesaikan tugas dalam rumah tangga.

d. Family Systems Theory.

Sistem kekeluargaan yang terdapat dalam setiap keluarga tidaklah sama, seperti dukungan istri dan masyarakat mengenai setuju atau tidaknya suami ikut serta dalam kegiatan rumah tangga. Persetujuan ini diberikan tergantung dari latar belakang budaya yang dianut istri dan masyarakat. Menurut Abdullah (1997), dalam masyarakat Jawa dianut paham patriarkis yang memihak kepada kaum laki-laki dan menekankan peranan perempuan sebagai ibu dan istri. Hal ini menghalangi suami untuk turut terlibat dalam urusan rumah tangga, karena rumah tangga merupakan wilayah istri.

e. Social Exchange Theory.

Dalam teori ini, segala kegiatan didasarkan atas perhitungan untungrugi. Bantuan yang diberikan oleh suami, diperhitungkan merupakan hal yang menguntungkan atau merugikan suami. Keuntungan yang didapat tidak saja dalam bentuk uang, tetapi juga dalam bentuk cinta, persahabatan, kekuasaan, status sosial dan lain-lain. Kerugian 
yang mungkin terjadi misalnya dalam bentuk kesepian, ketakutan dan kurangnya penghargaan. Dengan mengadakan komitmen yang harus disetujui bersama, rasa persaingan antara suami-istri dapat diatasi

Dari beberapa teori tersebut dapat disimpulkan bahwa keterlibatan suami dalam rumah tangga ditentukan oleh :

a. Pandangan masyarakat yaitu pantas tidaknya seorang suami ikut terlibat dalam kegiatan rumah tangga sesuai norma yang berlaku dalam masyarakat tersebut dan latar belakang budaya.

b. Adanya komitmen yang harus disetujui bersama oleh pasangan suami-istri dengan cara kompromi dan saling terbuka antara pasangan tersebut.

c. Adanya sikap saling menghargai antara suami dan istri sebagai perwujudan atas rasa cinta.

\section{Partisipasi Suami Istri Dalam Rumah Tangga}

Peran sebagai suami istri atau sebagai ayah-ibu, merupakan konsekuensi dari kehidupan perkawinan. Perkawinan merupakan suatu relasi antara dua orang individu yang memutuskan untuk hidup bersama dan membentuk keluarga baru. Di dalam perkawinan, masing-masing individu terikat oleh suatu hak dan kewajiban yang harus dilakukannya dalam kurun waktu yang tidak ditentukan, dan diharapkan kedua belah pihak saling menyesuaikan diri sejalan dengan tugas perkembangan kehidupan individu dalam keluarga. Duval dan Miller (1985) memberikan batasan mengenai perkawinan bahwa perkawinan bukan hanya merupakan legitimasi hubungan antara laki-laki dan perempuan, tetapi juga terdapat seperangkat hak dan kewajiban antara pasangan yang terlibat dalam perkawinan tersebut. Di sini terlihat bahwa dalam perkawinan adanya pembagian tugas dan peran dalam rumah tangga baik sebagai suami atau istri adalah dalam membesarkan anak secara bertanggung jawab. Pembagian tugas dan peran itu biasanya dilakukan berdasarkan kompromi dengan pasangannya. Sejauh mana suami terlibat dalam kegiatan dalam rumah tangga, tergantung dari hasil kompromi di antara pasangan suami istri tersebut.

Partisipasi suami dalam kegiatan rumah tangga juga dapat 
meningkatkan rasa kebersamaan terutama pada keluarga muda yang mempunyai karir ganda. Kehidupan keluarga muda karir ganda ini menimbulkan suatu pola hidup yang lebih kompleks dan membutuhkan keseimbangan, penyesuaian dan pengertian dari seluruh anggota keluarga agar tercapai suatu kehidupan perkawinan dan kehidupan keluarga yang memuaskan. Secara umum dikatakan oleh Rowatt (1990) bahwa para suami dan istri yang secara tulus mencintai pasangannya akan mengalami suatu semangat kerja sama yang baru. Kesediaan untuk memberikan diri, akan menahan goncangan-goncangan dan perbenturan kekuasaan serta memberi makna kembali kepada hubungan suami istri atas dasar keadilan.

Pentingnya peranan suami dalam kegiatan rumah tangga akan membantu menyelamatkan istri dari kelebihan peran, yaitu peran dalam keluarga dan peran dalam masyarakat, sehingga dengan demikian istri merasa dihargai dan suasana keluarga akan lebih baik. Bila suami ikut terlibat dalam kegiatan rumah tangga, minimal istri akan merasa terbantu karena perhatian suami. Apalagi jika istri adalah seorang pekerja, ada nilai kemandirian yang harus diterima oleh suami dalam kehidupan rumah tangga tersebut. Perkawinan merupakan bersatunya dua pihak atau dua posisi dalam kesederajatan, namun dalam mekanisme tugas berbedabeda sesuai jenis kelamin, pembawaan, dan kemampuan masing-masing. Oleh karena itu jika ingin sukses dalam mengelola rumah tangga ikutilah perkembangan zaman. Pada kenyataannya, dewasa ini masih banyak suami yang melimpahkan tugas-tugas rumah tangga hanya pada istri. Selama generasi yang ada perempuanlah yang mengerjakan pekerjaan rumah tangga seperti memasak, mencuci, dan mengasuh anak. Pria bertugas melakukan pekerjaan di luar seperti mencari nafkah, melindungi keluarga, memeriksa dan mengawasi ternak, dan sebagainya.

Seperti dijelaskan Rowatt (1990) bahwa walaupun revolusi industri membawa perubahan baik bagi laki-laki maupun perempuan, namun pada umumnya perempuan masih tetap mendapat bagian pekerjaan rumah tangga dalam porsi yang lebih besar. Seorang suami menjelaskan harapan-harapannya agar rumahnya menjadi semacam "stasiun pengisi bahan bakar" tempat setiap kali dia berhenti "mengisi bahan bakar" untuk segera melanjutkan perjalanan pada pekerjaan berikutnya. Seorang istri "dicetak" untuk menyiapkan makan, menata pakaian ke dalam koper 
suaminya yang akan bepergian, menjawab telepon yang ada hubungannya dengan pekerjaan, menyambut atasan dan istrinya dengan muka manis atau menyampaikan pesan-pesan dari atau ke perusahaan di mana suaminya bekerja.

Pendapat yang ada dalam masyarakat mengenai peran gender tercermin dalam sikap orang tua dan orang dewasa lainnya yang muncul dalam lingkup rumah tangga. Pendapat mengenai peran gender yang menjadi norma dalam suatu masyarakat akan membentuk pandangan yang bersifat normatif. Pandangan normatif mengenai bagaimana seharusnya hubungan peran antara seorang laki-laki dan seorang perempuan yang dikaitkan dengan kultur budaya disebut sebagai gender role ideology (Hurlock and Elizabeth, 1994). Selanjutnya dijelaskan bahwa pandangan mengenai peran gender ini bervariasi sepanjang suatu kontinum, dimulai dari pandangan tradisional sampai dengan pandangan modern yang menolak norma-norma yang berlaku secara tradisional dan menerima prinsip-prinsip egalitarian atau kesetaraan. Menurut Hurlock and Elizabeth (1994), pandangan normatif mengenai bagaimana seharusnya hubungan peran antara seorang laki-laki dan seorang perempuan, yang dikaitkan dengan kultur budaya disebut sebagai pandangan peran gender (gender role ideology). Pandangan ini bervariasi sepanjang suatu kontinum dimulai dari pandangan tradisional sampai dengan pandangan modern.

Adapun aspek-aspek pandangan peran gender menurut Duvall (1985) yang pertama adalah peran kerja dari laki-laki dan perempuan, yaitu aspek yang mencakup pembagian peran dalam pekerjaan yang dilakukan antara laki-laki dan perempuan dalam perkawinan. Kedua adalah tanggung jawab sebagai orang tua. Dalam hal ini meliputi tanggung jawab dan kewajiban orang tua terhadap anak-anaknya, terhadap masingmasing pasangan suami istri dan terhadap pekerjaan rumah tangga. Ketiga yaitu hubungan antar pribadi, dimana aspek ini mencakup aktivitas yang dilakukan baik suami ataupun istri yang berhubungan dengan orang lain selain pasangan tersebut di dalam perkawinannya. Keempat adalah peran khusus kodrat perempuan yaitu aspek yang menjelaskan tentang peran yang harus dilakukan isteri sebagai perempuan dalam kedudukannya baik di rumah tangga maupun di dalam masyarakat. Sedangkan yang terakhir adalah abortus dan homoseksualitas merupakan aspek yang meliputi sikap 
yang ditampilkan dalam berhubungan dengan sesama jenis dan sikap yang diambil terhadap aborsi dalam perkawinan.

Secara umum pergeseran pola relasi gender yang dipengaruhi budaya masyarakat dapat dijelaskan dalam tabel berikut :

Tabel 2. Perubahan Pola Relasi Gender Dalam Keluarga

\begin{tabular}{|l|l|}
\hline \multicolumn{1}{|c|}{ Tradisional } & \multicolumn{1}{c|}{ Modern } \\
\hline $\begin{array}{l}\text { Pencari nafkah utama adalah } \\
\text { suami }\end{array}$ & $\begin{array}{l}\text { Pencari nafkah utama adalah } \\
\text { suami dan istri }\end{array}$ \\
\hline $\begin{array}{l}\text { Suami meyakini nilai-nilai } \\
\text { pemingitan terhadap istri }\end{array}$ & $\begin{array}{l}\text { Suami mulai permisif ketika istri } \\
\text { masuk sektor publik }\end{array}$ \\
\hline $\begin{array}{l}\text { Istri fokus terhadap sektor } \\
\text { domestik }\end{array}$ & $\begin{array}{l}\text { Istri mulai independent dalam } \\
\text { membuat keputusan }\end{array}$ \\
\hline $\begin{array}{l}\text { Suami tidak terlibat dalam sektor } \\
\text { domestic }\end{array}$ & $\begin{array}{l}\text { Pembagian kerja mulai kabur, } \\
\text { tidak sexist dan tidak dikhotomis }\end{array}$ \\
\hline $\begin{array}{l}\text { Pembagian kerja sexist dikhotomis } \\
\text { Posisi istri sebagai mitra mulai } \\
\text { kelihatan }\end{array}$ \\
\hline $\begin{array}{l}\text { Posisi istri sebagai sub ordinasi } \\
\text { sangat kelihatan }\end{array}$ & $\begin{array}{l}\text { Pola relasi gender mengarah pada } \\
\text { androgini }\end{array}$ \\
\hline $\begin{array}{l}\text { Istri tidak independen dalam } \\
\text { membuat keputusan }\end{array}$ & $\begin{array}{l}\text { Sebagian suami tejun ke sektor } \\
\text { domestic }\end{array}$ \\
\hline $\begin{array}{l}\text { Pengasuhan anak tanggung jawab } \\
\text { utama istri }\end{array}$ & $\begin{array}{l}\text { Ada konflik yang bersifat } \\
\text { potensial dan manifest }\end{array}$ \\
\hline $\begin{array}{l}\text { Pola relasi gender lebih } \\
\text { didominasi maskulin dan feminin }\end{array}$ & $\begin{array}{l}\text { Pengasuhan anak mengarah pada } \\
\text { tanggung jawab bersama }\end{array}$ \\
\hline
\end{tabular}

\section{Kesimpulan}

Berdasarkan paparan di atas dapat dilihat bahwa keterlibatan suami dalam kegiatan rumah tangga sangat dipengaruhi oleh pandangan normatif dan budaya yang berlaku dalam masyarakat yang sesuai dengan peran jenisnya. Menurut peran jenis yang stereotip bagi laki-laki, mandiri adalah wajar bagi anak laki-laki, sedangkan sikap tergantung adalah tepat untuk anak perempuan. Hal seperti ini secara tradisional sudah ditanamkan dalam benak individu tentang kekhasan perilaku seorang perempuan (feminin) dan kekhasan perilaku seorang laki-laki (maskulin), yang oleh Hurlock disebut dengan peran gender dan yang akhirnya akan membentuk 
suatu pendapat yang dapat menjadi suatu norma dalam masyarakat. Masyarakat berpendapat bahwa perempuan secara fisik berbeda dengan laki-laki, misalnya perempuan melahirkan anak, suaranya lebih halus, buah dadanya lebih besar dan sebagainya. Karena keadaan fisik ini, secara psikologis perempuan berbeda dengan laki-laki, sehingga perempuan lebih emosional, lebih pasif dan lebih submisif sedangkan laki-laki dianggap lebih rasional, lebih aktif dan lebih agresif. Konstruk demikian, perlu mendapatkan pelurusan, sehingga implikasi negatif yang merugikan satu pihak dan menguntungkan pihak lain dapat diminimalisir.

\section{DAFTAR PUSTAKA}

Abdullah, I. ed. 1997. Sangkan Peran Gender. Yogyakarta: Pustaka Pelajar.

Atkinson, R.L., Atkinson, R.C. dan Hilgard, E.R. 1994. Pengantar Psikologi. Jilid I. Jakarta: Erlangga.

Berk, Laura E. 1989. Child Development. Massachusetts: Allyn and Bacon

Budiman, A. 1981. Pembagian Kerja Secara Seksual. Jakarta: Gramedia.

Dagun, S.M. 1992. Maskulin dan Feminin. Jakarta: Rineka Cipta.

Duvall, E.M. and Miller, B.C. 1985. Marriage and Family Development. New York: Harper and Row Publisher Inc.

Hurlock, Elizabeth B. 1994. Psikologi Perkembangan, Suatu Pendekatan Sepanjang Rentang Kehidupan. Jakarta: Erlangga.

Lindzey and Aronson. 1969. The Handbook of Social Psychology. Vol. I. New York: John Wiley and Sons.

Rowatt Jr, G. Wade dan Rowatt Mary Jo. 1990. Bila Suami Istri Bekerja. Yogyakarta: Kanisius.

Sconzoni, L.D. and John Sconzoni. 1981. Men, Women, and Change. USA: McGraw Hill Inc. 